Cybernetics: Journal Educational Research and Social Studies

Volume 2, Nomor 4, Oktober 2021

Journal Homepage: http://pusdikra-publishing.com/index.php/jrss

\title{
Penerapan Analisisi SWOT Dalam Manajemen Kurikulum Dan Pembelajaran Di SMK Putra Anda Binjai
}

\section{Rahmad Rinaldi}

Universitas Islam Negeri Sumatera Utara

Corresponding Author :@ naldi182683@gmail.com

ABSTRACT
$\begin{aligned} & \text { The quality mechanism in the education unit must be able to be implemented } \\ & \text { properly, so that the education unit always presents the best quality and strives } \\ & \text { to continuously improve the quality of what it has achieved. Quality is a measure } \\ & \text { for customers and users of education, namely parents, government and private } \\ & \text { agencies who will use the services of an education. Education is said to be of } \\ & \text { quality if there is a balance between input, process and output. Achievements } \\ & \text { with the application of SWOT Analysis based on logic that can maximize } \\ & \text { strengths and opportunities, so as to minimize weaknesses and threats at the } \\ & \text { same time. The results of writing about the application of SWOT analysis in } \\ & \text { curriculum management and learning at SMK Putra Anda Binjai are aimed at; 1) } \\ & \text { So that schools are able to detect and measure strengths, weaknesses, } \\ & \text { opportunities and threats, in order to follow up on the right strategy in improving } \\ & \text { the quality of curriculum and learning, 2) The process of applying SWOT analysis } \\ & \text { in Curriculum Management and Learning at SMK Putra Anda Binjai. }\end{aligned}$
KWata Kuncis Analysis, Quality

\section{PENDAHULUAN}

SMK Putra Anda Binjai merupakan sekolah menengah atas kejuruan pertama, yang didirikan oleh Yayasan Perguruan Putra Anda Sumatera Utara pada tahun 1995. Pada tahun 2011 sekolah ini menggunakan Standart Manajemen Mutu ISO 9001:2008, namun sekarang ini SMK Putra Anda Binjai tidak lagi menggunakan Standar Manajemen Mutu ISO 9001:2008.

Sebagaimana lembaga pendidikan setingkat lainnya, SMK Putra Anda Binjai juga melaksanakan 8 Standat Nasional Pendidikan (SPN) yang diamanatkan oleh Undang-Undang nomor 20 Tahun 2003 tentang Sistem Pendidikan Nasional BAB IX tentang SPN. 8 SNP ini terdiri dari; 1) standar isi, 2) standar proses pembelajaran, 3) standar kompetensi lulusan, 4) standar pendidik dan tenaga kependidikan, 5) standar sarana dan prasarana, 6) standar pengelolaan, 7) standar pembiayaan/biaya operasi, 8) dan standar penilaian pendidikan. Hanya saja riset ini lebih menfokuskan pada bagaimana penerapan manajemen kurikulum dan pembelajaran di SMK Putra Anda Binjai, serta apa saja kendala dan hambatan yang muncul dalam penerapan manajemen kurikulum dan pembelajaran di SMK Putra Anda Binjai. 
Cybernetics: Journal of Research and Educational Studies

Volume 2 Nomor 4, Oktober 2021

Halaman 96-102

\section{METODE PENELITIAN}

Metode yang digunakan dalam penulisan ini adalah: deskriptif dengan pendekatan kualitatif, yaitu merupakan pendekatan melalui kata-kata tertulis atau lisan dari orang-orang serta prilaku yang diamati. Proses pengumpulan data dilakukan dengan beberapa hal, antaralain pengumpulan dokumentasi, observasi, wawancara, terhadap pihak-pihak objek yang diteliti, dan selanjutnya dianalisis dengan analisis diskriptif kualitatif.

Riset dilakukan pada oktober 2021 sebagai pemenuhan tugas individu Mahasiswa Magister Manajemen Pendidikan Islam Universitas Islam Negeri Sumatera Utara dengan bimbingan dosen dalam kegiatan pemenuhan Tugas Ujian Tengah Semester (UTS).

\section{HASIL PENELITIAN DAN PEMBAHASAN}

Kurikulum merupakan poin penting serta acuan dalam proses pembelajaran. SMK Putra Anda Binjai menggunakan Kurikulum 20213 revisi yang telah disesuaikan dengan sekolah, sebagaimana yang sering disebut Kurikulum Tingkat Satuan Pendidikan 2013. Selalu dilaksanakan dalam penyusunan kurikulim sebelum tahun ajaran baru dimulai, dengan melakukan workshop yang diikuti oleh Kepala Sekolah, Wakil-wakil Kepala Sekolah, dan semua guru mata pelajaran, dengan melibatkan pihak industri (Du-Di). Kegiatan workshop ini, memberikan pemahaman bagi seluruh peserta tentang bagaimana penyusunan kurikulum ini sesuai dengan Permendikbud Nomor 20 Tahun 2016 tentang Standar Kompetensi Lulusan Pendidikan Dasar dan Menengah (SKL), termasuk juga SKKNI (Standar Kompetensi Kerja Nasional Indonesia).

Tim pengembangan kurikulum SMK Putra Anda Binjai yang terdiri dari; Wakil Kepala Sekolah Bidang Kurikulum, beserta stafnya, kepala jurusan dan ketua kelompok kerja tiap mata pelajaran, nantinya akan membuat kodifikasi kurikulum dalam bentuk buku kurikulum. Selanjutnya dari buku kurikulum ini lah kemudian akan lahirnya penyusunan silabus, program tahunan (prota), program semester (promes) dan Rencana Pelaksanaan Pembelajaran (RPP) yang di dalamnya terdapat Kompetensi Inti (KI), Kompetensi Dasar (KD), indikator hasil belajar, dan Penilaian Berbasis Kelas (PBK).

Dasar yang digunakan oleh guru dalam pelaksanaan pembelajaran adalah RPP, yang didalamnya include Kalender Pembelajaran guna pemetaan dan pengaturan waktu pembelajaran yang efektif, interaktif dan inovatif dengan media pembelajaran yang mendukung. Selain itu, guru juga akan memberikan ruang untuk siswa bereksplorasi dan elaborasi untuk mengembangkan kemampuan siswa. 
Penugasan dalam pembelajaran kepada siswa baik tugas terstruktur, tidak terstruktur dan tugas mandiri selalu dilakukan. Selain tugas terdapat juga ujian penilaian tengah semester dan penilaian semester. Setelah proses pembelajaran selesai dilaksanakan, guru melakukan evaluasi dari pemahaman yang diperoleh oleh siswa. Selain penilaian pembelajaran, guru juga melakukan evaluasi dari sikap siswa yang dapat diketahui dari lembar penilaian sikap yang di miliki oleh tiap guru mata pelajaran.

Skema alur pendelegasian tugas manajemen kurikulum di SMK Putra Anda Binjai;

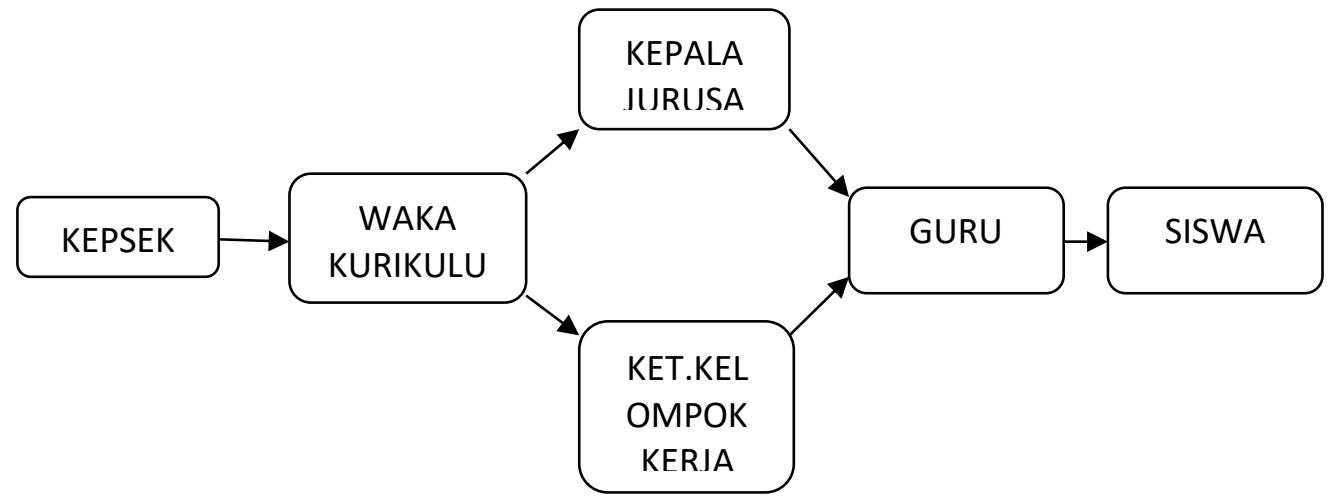

\section{Gambar.1 Skema alur pendelegasian tugas Manajemen Kurikulum SMK Putra Anda Binjai}

Skema diatas menunjukkan bahwa pelaksanaan kurikulum diawali dari kepala sekolah yang mendelegasikan kepada waka bidang kurikulum yang kemudian dari waka bidang kurikulum mendelegasikan tugas kepada kepala jurusan yang selanjutnya didelegasikan kepada ketua kelompok kerja. Selanjutnya dari ketua kelompok kerja akan mendelegasikan lagi kepada masing-masing guru mata pelajaran yang akan melaksanakannya bersama siswa.

Supervisi dan monitoring oleh kepala sekolah maupun wakil kepala sekolah dilakukan pada seluruh pelaksanaan kurikulum dan pembelajaran. Supervisi dilakukan setiap dua minggunya baik dikelas sebagai tempat pembelajaran teori maupun Lab Jurusan sebagai tempat pembelajaran praktek. Selanjutnya pelaksanaan kurikulum dikuatkan dengan beberapa factor pendukung, yaitu; 1) kemudahan atas informasi pembaharuan dan inovasi kurikulum, 2) evaluasi kurikulum secara berkesinambungan, setiap awal tahun pembelajaran, 3) good team player. 
Cybernetics: Journal of Research and Educational Studies

Volume 2 Nomor 4, Oktober 2021

Halaman 96-102

Pada dasarnya seluruh komponen sekolah sangat mendukung penerapan dan pelaksanaan manajemen kurikulum dan pembelajaran di SMK Putra Anda Binjai, namun terkadang yang menjadi kendala adalah masih ada guru yang terlambat dalam pengumpulan RPP, menurut pemaparan Sofyan Zuhri, ST Wakil Kepala Bidang Kurikulum. Sehingga melalui kepala sekolah yang diteruskan kepada waka kurikulum untuk menindak lanjuti solusi berupa mengingatkan para guru untuk segera mengumpulkan RPP, membuat deadline pengumpulan RPP, dan memberikan catatan khusus bagi guru yang terlambat. Ternyata Solusi ini cukup produktif dalam penyelesaian masalah ini.

\section{Analisis Swot}

Berikut adalah analisis terhadap kekuatan, kelemahan, peluang, dan ancaman pada manajemen kurikulum dan pembelajaran;

\begin{tabular}{|c|c|}
\hline $\begin{array}{l}\text { KEKUATAN } \\
\text { (Strengths) }\end{array}$ & $\begin{array}{l}\text { 1. Good team player/ Kerja sama tim yang solid. } \\
\text { 2. Memiliki muatan local dan muatan identitas didalam } \\
\text { kurikulum. } \\
\text { 3. Silabus yang berkesinambungan dengan RPP. } \\
\text { 4. Penyusunan kurikulum yang transparan. } \\
\text { 5. Evaluasi kurikulum secara rutin setiap tahun. }\end{array}$ \\
\hline $\begin{array}{l}\text { KELEMAHAN } \\
\text { (Weaknesses) }\end{array}$ & $\begin{array}{l}\text { Masih ditemuinya keterlambatan penyusunan dan } \\
\text { penyerahan RPP oleh guru. }\end{array}$ \\
\hline $\begin{array}{c}\text { PELUANG } \\
\text { (Opportunities) }\end{array}$ & $\begin{array}{l}\text { 1. Kemudahan mendapatkan informasi mengenai } \\
\text { pembaharuan kurikulum. } \\
\text { 2. Peran serta industri/ Du-Di dalam memberikan masukan } \\
\text { untuk penyusunan kurikulum. }\end{array}$ \\
\hline $\begin{array}{l}\text { ANCAMAN } \\
\text { (Threats) }\end{array}$ & Adanya sistem pendidikan yang berubah-ubah. \\
\hline
\end{tabular}

Tabel.1 Analisis Manajemen Kurikulum dan Pembelajaran

Dari analisis diatas, dapat dilakukan empat strategi peningkatan mutu dalam bidang kurikulum dan pembelajaran, yaitu;

\section{Strategi SO; menggunakan kekuatan dan memanfaatkan peluang}

Kekuatan yang dimiliki SMK Putra Anda Binjai dalam peningkatan manajemen kurikulum dan proses pembelajaran, berupa; kerja sama tim yang solid menjadi, penyusunan kurikulum yang transparan, didukung dengan isi atau muatan kurikulum yang disesuaikan dengan lingkungan dan budaya sekolah, silabus yang berkesinambungan dengan RPP dan evaluasi kurikulum 
Cybernetics: Journal of Research and Educational Studies

Volume 2 Nomor 4, Oktober 2021

Halaman 96-102

yang dilakukan secara rutin, sehingga dapat diukur tingkat keberhasilan pelaksanaan kurikulum di SMK Putra Anda Binjai.

Akan lebih maksimal keberhasilan penggunaan kekuatan jika peluang mampu dikelola dan manfaatkan. Beberapa peluang yang dimiliki SMK Putra Anda Binjai adalah 1) kemudahan mendapatkan informasi mengenai pembaharuan kurikulum, sehingga SMK Putra Anda Binjai dapat dengan cepat dan mudah sehingga tidak tertinggal, 2) peran serta industry/ Du-Di dalam memberikan masukan untuk penyusunan kurikulum guna memberikan masukan terhadap kompetensi yang dibutuhkan oleh Du-Di sekarang, sehingga sekolah dapat menyusun kurikulum yang selaras dengan kebutuhan pasar. Dengan memadukan dua unsur kekuatan dan peluang ini, sesungguhnya SMK Putra Anda Binjai dapat menyusun isi maupun proses pembelajaran yang unggul, dan terus meningkatkan, memperbaiki serta mengembangkan kurikulum yang ada.

\section{Strategi WO; memperbaiki kelemahan dan memanfaatan peluang}

Kelemahan yang muncul pada SMK Putra Anda Binjai terkait manajemen kurikulum dan pembelajaran adalah terlambatnya penyusunan dan penyerahan RPP oleh guru, namun hal tersebut telah ditangani oleh wakil kepala sekolah bidang kurikulum dengan membuat deadline pengumpulan RPP, dan memberikan catatan khusus bagi guru yang terlambat.

Selain itu perlu adanya pemanfaatan peluang untuk menekan kelemahan. Kemudahan mendapatkan informasi sebenarnya dapat dijadikan sebagai penekan kelemahan, sebab kemudahan mendapatkan informasi bagi guru akan memudahkan guru dalam menyusun dan menyelesaikan RPP, sehingga pengumpulan RPP tidak akan terlambat lagi.

\section{Strategi ST; menggunakan kekuatan dan menghindari ancaman}

Kerjasama tim yang solid/ good team player dalam hal penyusunan kurikulum, sesungguhnya memudahkan pengembangan kurikulum yang sesuai dengan keadaan dan budaya sekolah, membuat penyusunan kurikulum yang transparan, serta evaluasi kurikulum yang dilakukan secara rutin setiap tahunnya. Sesungguhnya hal tersebut merupakan cara guna menekan dan mengatasi adanya sistem pendidikan yang sering kali berubah.

\section{Strategi WT; mengatasi kelemahan dan menghindari ancaman}

Antisipasi terhadap kemungkinan adanya keterlambatan penyususnan RPP oleh guru harus diperhatikan secara serius dan harus diperbaiki, sehingga proses pembelajaran tidak terganggu dan dapat berjalan dengan baik.

Ketika kita melihat diskripsi tabel diatas, maka tampak kelemahan dan ancaman yang dihadapi oleh SMK Putra Anda Binjai dalam bidang kurikulum dan pembelajaran, yaitu; keterlambatan pengumpulan RPP oleh guru. Meskipun 
Cybernetics: Journal of Research and Educational Studies

Volume 2 Nomor 4, Oktober 2021

Halaman 96-102

kelemahan dan ancaman tersebut mampu diatasi dengan menanamkan rasa tanggungjawab, integritas dan disiplin kepada guru, dengan cara memberikan batas waktu pengumpulan RPP. Dan jika dalam batas waktu yang telah ditentukan tersebut masih ada guru yang masih belum mengumpulkan RPP maka perlu adanya pemberian peringatan atau sanksi terhadap guru tersebut. Selain kelemahan terdapat juga ancaman bagi SMK Putra Anda Binjai yaitu, adanya perubahan system pendidikan. Untuk menghadapi ancaman tersebut perlu adanya sistem informasi yang baik di sekolah dan perlu adanya tim penyusun kurikulum yang berkompeten dan solid.

\section{KESIMPULAN}

Penerapan Analisis SWOT Dalam Manajemen Kurukulum Dan Pembelajaran Di SMK Putra Anda Binjai akhirnya mampu mendeteksi serta mengukur kekuatan, kelemahan, peluang dan ancaman, guna menindak lanjuti terhadap strategi yang tepat dalam meningkatkan mutu kurikulum dan pembelajaran, serta mampu melakukan pemetaan terhadap kendala dan hambatan yang muncul dalam penerapan manajemen kurikulum dan pembelajaran di SMK Putra Anda Binjai.

Analisis terhadap kekuatan, kelemahan, peluang, dan ancaman pada manajemen kurikulum dan pembelajaran;

\begin{tabular}{|c|c|}
\hline $\begin{array}{l}\text { KEKUATAN } \\
\text { (Strengths) }\end{array}$ & $\begin{array}{l}\text { 1. Good team player/ Kerja sama tim yang solid. } \\
\text { 2. Memiliki muatan local dan muatan identitas didalam } \\
\text { kurikulum. } \\
\text { 3. Silabus yang berkesinambungan dengan RPP. } \\
\text { 4. Penyusunan kurikulum yang transparan. } \\
\text { 5. Evaluasi kurikulum secara rutin setiap tahun. }\end{array}$ \\
\hline $\begin{array}{l}\text { KELEMAHAN } \\
\text { (Weaknesses) }\end{array}$ & $\begin{array}{l}\text { Masih ditemuinya keterlambatan penyusunan dan } \\
\text { penyerahan RPP oleh guru. }\end{array}$ \\
\hline $\begin{array}{c}\text { PELUANG } \\
\text { (Opportunities) }\end{array}$ & $\begin{array}{l}\text { 1. Kemudahan mendapatkan informasi mengenai } \\
\text { pembaharuan kurikulum. } \\
\text { 2. Peran serta industri/ Du-Di dalam memberikan masukan } \\
\text { untuk penyusunan kurikulum. }\end{array}$ \\
\hline $\begin{array}{l}\text { ANCAMAN } \\
\text { (Threats) }\end{array}$ & Adanya sistem pendidikan yang berubah-ubah. \\
\hline
\end{tabular}

Dari analisis diatas, dapat dilakukan empat strategi peningkatan mutu dalam bidang kurikulum dan pembelajaran, yaitu; 1) Strategi SO; menggunakan kekuatan dan memanfaatkan peluang, 2) Strategi WO; memperbaiki kelemahan dan memanfaatan peluang, 3) Strategi ST; menggunakan kekuatan dan 
Cybernetics: Journal of Research and Educational Studies

Volume 2 Nomor 4, Oktober 2021

Halaman 96-102

menghindari ancaman, 4) Strategi WT; mengatasi kelemahan dan menghindari ancaman.

\section{REFERENCE}

Agus Salim Chamidi dan Tutik Rodhiana, 2018. “Upaya Penguatan Manajemen

Pendidikan Baca Tulis Al-Qur'an (BTQ) Studi Kasus di Sekolah Dasar Negeri 1 Kutowinangun", Jurnal Cakrawala, Volume 2, Nomor 1, Tahun 2018

Albi Anggito dan Johan Setiawan.2018.Metode Penelitian Kualitatif.Cet.1Sukabumi: CV. Jejak.

Agus Salim Chamidi 2019: Studi Manajemen Pendidikan Islam Dan Studi Sosial Ejournal, Cakrawla Vol. 3 No.2.

David Wijaya, 2009. “Manajemen Sumber Daya Manusia Penedidikan Berbasis Kompetensi Guru dalam Rangka Membangun Keunggulan Bersaing Sekolah", Jurnal Pendidikan Penabur, Nomor 12,Tahun ke-8, Juni 2009

Luki Eko Cahyono, Satrijo Budiwibowo, Juli Murwani, 2015. “Analisis penerapan 8 Standar Nasional Pendidikan pada SMP Negeri 2 Dolopo Kabupaten Madiun", Jurnal Assets, Volume 4, Nomor 2, Oktober 2015Mahmud. 2011. Metode Penelitian Pendidikan.Bandung: CV. Pustaka Setia.

Peraturan Menteri Pendidikan dan Kebudayaan RI Nomor 34 Tahun 2018 tentang Standar Nasional Pendidikan Sekolah Menengah Kejuruan/Madrasah Aliyah Kejuruan.

Undang Undang Nomor 20 Tahun 2003 tentang Sistem pendidikan Nasional 